\title{
Case Report of Cardiac Mass in an Infant
}

\author{
Mahmoud AlSoufi* \\ Consultant Pediatric Cardiologist, Al-Jalila Children Speciality Hospital, UAE
}

Submission: February 07, 2018; Published: March 19, 2018

*Corresponding author: Mahmoud AlSoufi, Consultant Pediatric Cardiologist, Al-Jalila Children Speciality Hospital, Dubai, UAE, Tel: 00971553405476; Email: dr.m.soufi@hotmail.com

\begin{abstract}
Cardiac tumors can be benign or malignant. Primary cardiac tumors are rare in paediatric practice with a prevalence of 0.0017 to 0.28 in autopsy series. In contrast, the incidence of cardiac tumors during fetal life has been reported to be approximately $0.14 \%$. We are presenting a case of an infant born in good condition with three intra-cardiac masses in which two of them attached to each other adjacent to RVOT.
\end{abstract}

\section{The Case}

Baby of S.R. born at term 37 gestational weeks, maternal age 32 years old, maternal screen for (HIV, HBV, Syph, GBS) were negative. Fetal scanning showed intra-cardiac echogenic foci at the level of AV junction. He born with good apgars 8/9/9 at $1 / 5 / 10$ minutes.

\section{On examination}

He looks comfortable in himself, active, well perfused, no distress, precordium looks normal. CVS: S1 normal +S2 splitted, can hear additional sound like? friction. Regular rhythm, 2-3/6ESM/LSUE murmur, no thrill, no gallop Femorals and peripherals pulses are good.

\section{Family Hx}

Paternal grandmother operated at age of 18 years due to large chest tumour and maternal grandfather was operated for meningioma. The baby had recent follow up at two weeks age, he is free from cardiac signs and symptoms, and not on medications. No arrhythmias have been detected so far. The echo showed same size of the masses.

\section{Echo with Doppler study showed}

a) Levocardia, Situs Solitus, AV/VA Connections Concordance, Great Vessels Normal, SVC and IVC to RA, No LSVC, Normal 4 PVs to LA. MV normal. Minimal TR. Small PFO L to R shunt. Small PDA - closed on follow up. PAs normal, normal tricuspid AoV. Normal left Ao arch. Normal coronaries. Good cardiac function EF 64\%.

b) Dilated RA with small mass at SVC-RA junction nonobstruction. c) Dilated RV, RV has 2 masses attached to each other, and attached to IVS and obstructing the RVOT, both masses size 11 $\mathrm{x} 16 \mathrm{~mm}$.

d) Inter-Vent Septum is hypertrophied, to it attached one mass.

e) Pulmonary Valve Normal with significant obstruction with large mass, with flow acceleration PG 50-55mmHg.

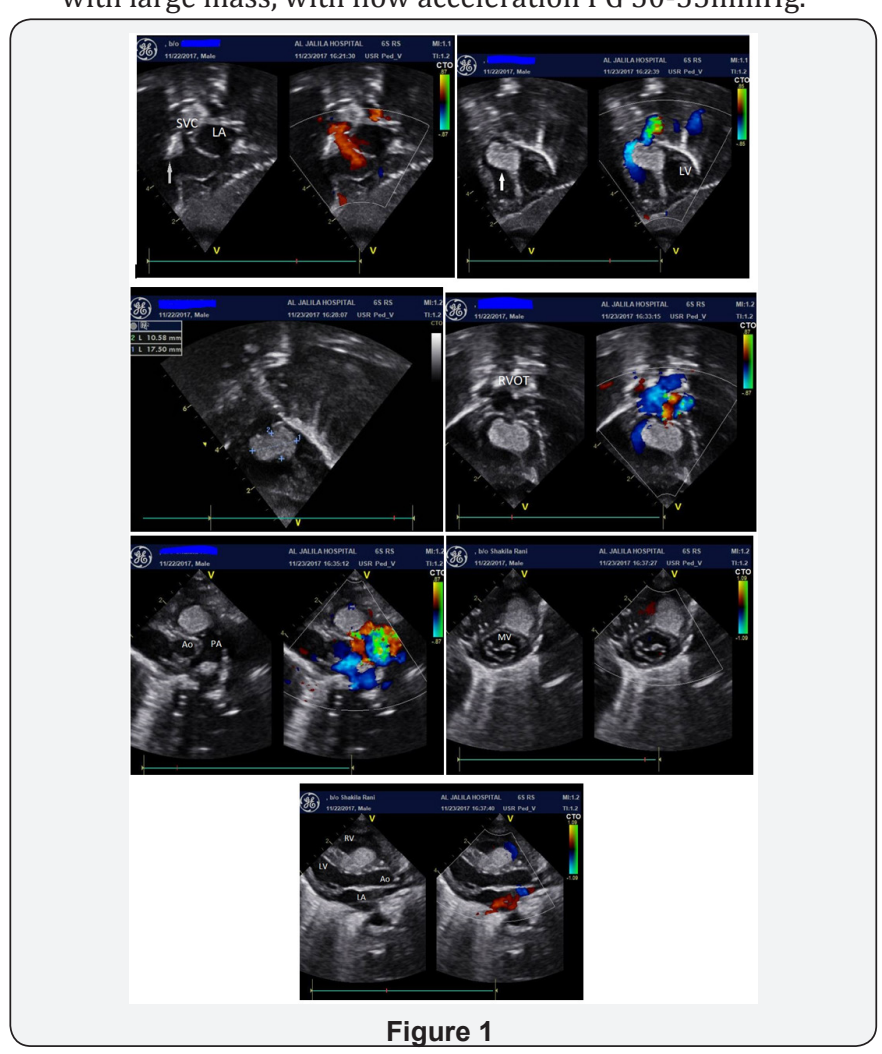


He was observed in the CICU for a period of time while the PDA was still open, and as it was shrinking, no change to his status. His saturations were maintained $91-95-100 \%$ in room air pre and post the PDA closed. BP 69/40-97/63mmHg, HR 102-159bpm, RR $26-52 / \mathrm{min}$ and currently he is stable (Figure 1 ).

\section{Discussion}

Cardiac tumors usually are found on routine echocardiographic studies when the diagnosis is not suspected, especially in small infants. In infants (younger than 12 months), Benign Tumors accounts for $94 \%$ of cases, while Malignant Tumors account for $6 \%$ of cases.

a) Benign Tumors: Rhabdomyoma, Fibroma, Hemangioma, Teratoma.

b) Malignant Tumors: Rhabdomyosarcoma, Leiomyosarcoma.

c) In USA as per Medscape: Primary cardiac tumors are rare, with a frequency of $0.0017-0.28 \%$ based on autopsies. About $75 \%$ of them are benign and $25 \%$ are malignant.
Cardiac rhabdomyomas are the most frequent primary cardiac tumors in infancy and childhood and in about $50 \%$ of cases are associated with tuberous sclerosis [1-5]. Our baby case is still stable on regular follow up, no increase in masses size so far, maintaining saturations well, feeding, and growing well. He will be screened for tuberous sclerosis as well as family members.

\section{References}

1. Uzun O, Wilson DG, Vujanic GM, Parsons JM, De Giovanni JV (2007) Cardiac tumours in children. Orphanet J Rare Dis 2: 11.

2. Park MK (2014) Park's pediatric cardiology for practitioners. $\left(6^{\text {th }}\right.$ edn $)$, Mosby, USA.

3. Becker AE (2000) Primary heart tumors in the pediatric age group: a review of salient pathologic features relevant for clinicians. Pediatr Cardiol 21(4): 317-323.

4. Patnana SR, Rodriguez-Cruz E, Ross RD, Towbin JA (2016) Pediatric cardiac tumors. Medspace.

5. Neri G, Alitto F, Berzioli M (1988) Cardiac rhabdomyoma in a newborn infant with tuberous sclerosis. Value of 2-dimensional and Doppler echocardiography. G Ital Cardiol 18(12): 1028-1030.

\begin{tabular}{|l|}
\hline \multicolumn{1}{|c|}{ Your next submission with Juniper Publishers } \\
will reach you the below assets \\
- Quality Editorial service \\
- Swift Peer Review \\
- Reprints availability \\
- E-prints Service \\
- Manuscript Podcast for convenient understanding \\
- Global attainment for your research \\
- Manuscript accessibility in different formats \\
( Pdf, E-pub, Full Text, Audio) \\
- Unceasing customer service \\
Track the below URL for one-step submission \\
https://juniperpublishers.com/online-submission.php \\
\hline
\end{tabular}

